\title{
Front Matter: Volume 8923
}

, "Front Matter: Volume 8923," Proc. SPIE 8923, Micro/Nano Materials, Devices, and Systems, 892301 (6 January 2014); doi: 10.1117/12.2053914

EPIE Event: SPIE Micro+Nano Materials, Devices, and Applications, 2013, SPIE. Melbourne, Victoria, Australia 


\title{
PROCEEDINGS OF SPIE
}

\section{Micro/Nano Materials, Devices, and Systems}

\author{
James Friend \\ H. Hoe Tan \\ Editors
}

9-11 December 2013

Melbourne, Australia

Sponsored by

Australian National Fabrication Facility (Australia)

Grey Innovation (Australia)

Melbourne Centre for Nanofabrication (Australia)

MicroNano Research Facility (Australia)

RMIT University (Australia)

Published by

SPIE 
The papers included in this volume were part of the technical conference cited on the cover and title page. Papers were selected and subject to review by the editors and conference program committee. Some conference presentations may not be available for publication. The papers published in these proceedings reflect the work and thoughts of the authors and are published herein as submitted. The publisher is not responsible for the validity of the information or for any outcomes resulting from reliance thereon.

Please use the following format to cite material from this book:

Author(s), "Title of Paper," in Micro/Nano Materials, Devices, and Systems, edited by James Friend, H. Hoe Tan, Proceedings of SPIE Vol. 8923 (SPIE, Bellingham, WA, 2013) Article CID Number.

ISSN: 0277-786X

ISBN: 9780819498144

Published by

SPIE

P.O. Box 10, Bellingham, Washington 98227-0010 USA

Telephone +1 3606763290 (Pacific Time) · Fax +1 3606471445

SPIE.org

Copyright $@ 2013$, Society of Photo-Optical Instrumentation Engineers.

Copying of material in this book for internal or personal use, or for the internal or personal use of specific clients, beyond the fair use provisions granted by the U.S. Copyright Law is authorized by SPIE subject to payment of copying fees. The Transactional Reporting Service base fee for this volume is $\$ 18.00$ per article (or portion thereof), which should be paid directly to the Copyright Clearance Center (CCC), 222 Rosewood Drive, Danvers, MA 01923. Payment may also be made electronically through $\mathrm{CCC}$ Online at copyright.com. Other copying for republication, resale, advertising or promotion, or any form of systematic or multiple reproduction of any material in this book is prohibited except with permission in writing from the publisher. The CCC fee code is $0277-786 \mathrm{X} / 13 / \$ 18.00$.

Printed in the United States of America.

Publication of record for individual papers is online in the SPIE Digital Library.

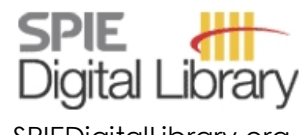

SPIEDigitalLibrary.org

Paper Numbering: Proceedings of SPIE follow an e-First publication model, with papers published first online and then in print and on CD-ROM. Papers are published as they are submitted and meet publication criteria. A unique, consistent, permanent citation identifier (CID) number is assigned to each article at the time of the first publication. Utilization of CIDs allows articles to be fully citable as soon as they are published online, and connects the same identifier to all online, print, and electronic versions of the publication. SPIE uses a six-digit CID article numbering system in which:

- The first four digits correspond to the SPIE volume number.

- The last two digits indicate publication order within the volume using a Base 36 numbering

system employing both numerals and letters. These two-number sets start with 00, 01, 02, 03, 04,

$05,06,07,08,09,0 A, 0 B \ldots$. OZ, followed by 10-1Z, 20-2Z, etc.

The CID Number appears on each page of the manuscript. The complete citation is used on the first page, and an abbreviated version on subsequent pages. Numbers in the index correspond to the last two digits of the six-digit CID Number. 


\section{Contents}

\section{Part One}

xvii Conference Committees

xxi Nano-architecture: creating complex surface structures using supramolecular selfassembly of tripeptides (Invited Paper Summary) [8923-58]

A. Mechler, R. Seoudi, La Trobe Univ. (Australia); M. P. Del Borgo, M.-I. Aguilar, P. Perlmutter, Monash Univ. (Australia)

xxv Synthesis and electrochemical characterization of novel MOF-reduced graphene oxide composites (Summary) [8923-95]

P. Chakraborty Banerjee, R. Cnr, D. Lobo, M. Miansari, M. Majumder, Monash Univ. (Australia)

xxvii Tunable reduction and amorphisation of graphene oxide films by focused ion beam irradiation (Summary) [8923-120]

D. E. Lobo, J. Fu, Monash Univ. (Australia); T. Gengenbach, Commonwealth Scientific and Industrial Research Organisation (Australia); M. Majumder, Monash Univ. (Australia)

\section{FABRICATION I}

892305 Black-Si as a platform for sensing [8923-1]

G. Gervinskas, P. Michaux, G. Seniutinas, J. S. Hartley, Swinburne Univ. of Technology (Australia); E. L. H. Mayes, RMIT Univ. (Australia); R. Verma, B. D. Gupta, Indian Institute of Technology Delhi (India); P. R. Stoddart, D. Morrish, N. F. Fahim, M. S. Hossain, Swinburne Univ. of Technology (Australia); S. Juodkazis, Swinburne Univ. of Technology (Australia) and Australian National Fabrication Facility (Australia)

892306 Development of silicon optics for an integrated micro-optical system-on-a-chip [8923-4] D. C. Ng, National ICT Australia (Australia) and The Univ. of Melbourne (Australia); S. Kandasamy, Australian National Fabrication Facility (Australia); E. Skafidas, The Univ. of Melbourne (Australia)

\section{SOLAR I}

892307 Enhanced photovoltaic performance of dye-sensitized solar cell using composite photoanode on 3D electrode [8923-5]

C. K. Lim, Nanyang Technological Univ. (Singapore); H. Huang, A*STAR Singapore Institute of Manufacturing Technology (Singapore); M. S. Tse, O. K. Tan, Nanyang Technological Univ. (Singapore) 
892308 Mixed metal oxides for dye-sensitized solar cell using zinc titanium layered double hydroxide as precursor [8923-6]

J. Liu, Y. Qin, L. Zhang, H. Xiao, J. Song, D. Liu, M. Leng, W. Hou, N. Du, Shandong Univ. (China)

8923 OA Direct transfer of solar radiation to high temperature applications [8923-8]

M. Rahou, J. Andrews, G. Rosengarten, RMIT Univ. (Australia)

\section{NANOMATERIALS I}

8923 OB Fluorescent emission in different silicon carbide polytypes [8923-9]

S. Castelletto, RMIT Univ. (Australia); B. C. Johnson, The Univ. of Melbourne (Australia);

I. Aharonovich, Univ. of Technology Sydney (Australia); A. Parker, RMIT Univ. (Australia)

8923 OC Graphene-polymer multilayer heterostructure for terahertz metamaterials [8923-214]

Z. Xu, Monash Univ. (Australia); C. Chen, Soochow Univ. (China); S. Q. Y. Wu, B. Wang, J. Teng, A*STAR Institute of Materials Research and Engineering (Singapore); C. Zhang,

Univ. of Wollongong (Australia); Q. Bao, Monash Univ. (Australia)

8923 OD Density functional theory calculations of phenol-modified monolayer silicon nanosheets [8923-11]

M. J. S. Spencer, RMIT Univ. (Australia) and La Trobe Univ. (Australia); T. Morishita, National Institute of Advanced Industrial Science and Technology (Japan); M. R. Bassett, La Trobe Univ. (Australia)

BIO I

8923 OF Challenges in specificity and collection efficiency for integrated optical biosensors (Invited Paper) [8923-13]

A. M. Armani, Mork Family Dept. of Chemical Engineering and Materials Science, The Univ. of Southern California (United States) and Mork Family Dept. of Chemical Engineering and Materials Science, The Univ. of Southern California (United States); S. Mehrabani, A. J. Maker, C. Lopez, Mork Family Dept. of Chemical Engineering and Materials Science, The Univ. of Southern California (United States); M. C. Harrison, Mork Family Dept. of Chemical Engineering and Materials Science, The Univ. of Southern California (United States)

$8923 \mathrm{Ol} \quad$ Nanosensors for next generation drug screening [8923-16]

S. K. Kannam, IBM Research Australia (Australia); M. T. Downton, IBM Research Collaboratory for Life Sciences-Melbourne (Australia); N. Gunn, S. C. Kim, P. R. Rogers, C. Schieber, J. S. Baldauf, IBM Research Australia (Australia); J. M. Wagner, IBM Research Collaboratory for Life Sciences-Melbourne (Australia); D. Scott, R. Bathgate, S. Skafidas, The Univ. of Melbourne (Australia); S. Harrer, IBM Research Australia (Australia) 
8923 OK Third-order optical nonlinearity in BDN dye encapsulated polymer matrix induced by nanosecond laser pulses [8923-19]

D. Mohan, P. Arya, Guru Jambheshwar Univ. of Science and Technology (India); A. Kumar, Instruments Research \& Development Establishment (India)

8923 OM Translation interference pattern in nano-scale precision by phase control based on spatial light modulator [8923-21]

J. Ma, Y. Zhong, Z. Chen, Jinan Univ. (China); K. S. Wong, Hong Kong Univ. of Science and Technology (China)

$8923 \mathrm{ON}$ Constructing microstructures using the optical trapping map of dielectric spheres [8923-22] M. Muradoglu, Monash Univ. (Australia)

\section{MATERIALS I}

892300 Hydride VPE: the unexpected process for the fast growth of GaAs and GaN nanowires with record aspect ratio and polytypism-free crystalline structure (Invited Paper) [8923-23] Y. . André, CNRS, Institut Pascal, Univ. Blaise Pascal-Clermont II (France) and CNRS, UMR 6602 (France ); A. Trassoudaine, CNRS, Institut Pascal, Univ. Blaise Pascal-Clermont II (France) and CNRS, UMR 6602 (France) and Univ. d'Auvergne Clermont-Ferrand I (France); G. Avit, K. Lekhal, M. R. Ramdani, CNRS, Institut Pascal, Univ. Blaise Pascal-Clermont II (France) and CNRS, UMR 6602 (France ); C. Leroux, CNRS, Univ. du Sud Toulon-Var (France); G. Monier, C. Varenne, P. Hoggan, D. Castelluci, CNRS, Institut Pascal, Univ. Blaise Pascal-Clermont II (France) and CNRS, UMR 6602 (France) ); C. Bougerol, Institut NÉEL, CEACNRS-Univ. Joseph Fourier (France); F. Réveret, J. Leymarie, CNRS, Institut Pascal, Univ. Blaise Pascal-Clermont II (France) and CNRS, UMR 6602 (France); E. Petit, Institut de Chimie de Clermont-Ferrand, Univ. Blaise Pascal-Clermont II (France); V. Dubrovskii, St. Petersburg Academic Univ. (Russian Federation) and loffe Physico-Technical Institute (Russian Federation)

8923 OP In situ monitoring of resistivity and carrier concentration during molecular beam epitaxy of topological insulator $\mathrm{Bi}_{2} \mathrm{Se}_{3}$ [8923-24]

J. Hellerstedt, Monash Univ. (Australia) and Univ. of Maryland, College Park (United States); J. H. Chen, D. Kim, W. G. Cullen, Univ. of Maryland, College Park (United States); C. X. Zheng, Monash Univ. (Australia); M. S. Fuhrer, Monash Univ. (Australia) and Univ. of Maryland, College Park (United States)

$89230 Q$ Effect of compositional gradient on mechanical properties in aluminum/duralumin multi-layered clad structures [8923-25]

H. Tsukamoto, Nagoya Institute of Technology (Japan); Y. Komiya, Nihon Univ. (Japan); H. Sato, Y. Watanabe, Nagoya Institute of Technology (Japan)

8923 OR Electron spin resonance spectroscopy of high purity crystals at millikelvin temperatures [8923-26]

W. G. Farr, D. L. Creedon, M. Goryachev, The Univ. of Western Australia (Australia); K. Benmessai, The Univ. of Western Australia (Australia) and Ctr. de Développement des Téchnologies Avancées (Algeria); M. E. Tobar, The Univ. of Western Australia (Australia) 
8923 OS Composite anode $\mathrm{La}_{0.8} \mathrm{Sr}_{0.2} \mathrm{MnO}_{3}$ impregnated with cobalt oxide for steam electrolysis [8923-27]

S. Li, J. Cheng, K. Xie, P. Li, Y. Wu, Hefei Univ. of Technology (China)

\section{MICROFLUIDICS I}

8923 OU Small volume particulate and non-particulate sample collection for fluidic systems [8923-29]

B. H. Cheong, Monash Univ. (Australia)

\section{PLASMONICS I}

$89230 Z$ Simulation of the gap plasmon coupling with a quantum dot [8923-34]

C. Perera, K. C. Vernon, Queensland Univ. of Technology (Australia)

892312 Polarization effect and emission control in asymmetric cross-shaped slot antennas surrounded with periodic corrugations [8923-37]

A. Djalalian-Assl, J. Cadusch, The Univ. of Melbourne (Australia); T. D. James, The Univ. of Melbourne (Australia) and Australian National Fabrication Facility (Australia); T. J. Davis, Commonwealth Scientific and Industrial Research Organisation (Australia) and Australian National Fabrication Facility (Australia); A. Roberts, The Univ. of Melbourne (Australia)

BIO II

892319 Water-soluble benzylidene cyclopentanone photosensitizers for two-photon excited photodynamic therapy [8923-44]

Y. Fang, Technical Institute of Physics and Chemistry (China) and Graduate Univ. of Chinese Academy of Sciences (China); H. Zhao, Chinese PLA General Hospital (China);

Q. Zou, Technical Institute of Physics and Chemistry (China) and Graduate Univ. of Chinese Academy of Sciences (China); Y. Zhao, Technical Institute of Physics and Chemistry (China); Y. Gu, Chinese PLA General Hospital (China); F. Wu, Technical Institute of Physics and Chemistry (China)

$89231 \mathrm{~A}$ Effects of laser-exposed gold nanorods on biochemical pathways of neuronal cells [8923-45]

C. Paviolo, Swinburne Univ. of Technology (Australia); J. W. Haycock, The Univ. of Sheffield (United Kingdom); P. R. Stoddart, S. L. McArthur, Swinburne Univ. of Technology (Australia)

8923 1B Influence of surface acoustic waves induced acoustic streaming on the kinetics of electrochemical reactions [8923-46]

S. Tietze, J. Schlemmer, G. Lindner, Hochschule für angewandte Wissenschaften und Künste Coburg (Germany)

8923 1C Laser measurements of bacterial endospore destruction from shock waves [8923-47] P. P. Lappas, RMIT Univ. (Australia); A. D. McCartt, S. D. Gates, J. B. Jeffries, R. K. Hanson, Stanford Univ. (United States) 
$8923 \mathrm{lE} \quad$ Characterization of optical polarization converters made by femtosecond laser writing [8923-198]

C. J. de Jong, Swinburne Univ. of Technology (Australia) and Technische Univ. Eindhoven (Netherlands); A. Lajevardipour, Swinburne Univ. of Technology (Australia); M. Gecevičius, M. Beresna, Univ. of Southampton (United Kingdom); G. Seniutinas, G. Gervinskas,

R. Buividas, Swinburne Univ. of Technology (Australia); P. G. Kazansky, Univ. of Southampton (United Kingdom); Y. Bellouard, Technische Univ. Eindhoven (Netherlands); A. H. A. Clayton, Swinburne Univ. of Technology (Australia); S. Juodkazis, Swinburne Univ. of Technology (Australia) and Australian National Fabrication Facility (Australia)

$8923 \mathrm{IF}$ The application of carbon nanotubes in mode locked fiber laser [8923-50]

Z. Yu, Beijing Univ. of Technology (China); Y. Wang, Xi'an Institute of Optics and Precision Mechanics (China); Y. Song, Beijing Univ. of Technology (China)

$89231 \mathrm{G}$ Comparison of $\mathrm{Al}_{2} \mathrm{O}_{3}$ nano-overlays deposited with magnetron sputtering and atomic layer deposition on optical fibers for sensing purposes [8923-51]

M. Śmietana, T. Drqżewski, P. Firek, Warsaw Univ. of Technology (Poland); P. Mikulic,

W. J. Bock, Univ. du Québec en Outaouais (Canada)

SOLAR II

$89231 \mathrm{~J} \mathrm{Heterogeneous} \mathrm{nano-particle} \mathrm{array} \mathrm{for} \mathrm{the} \mathrm{realization} \mathrm{of} \mathrm{the} \mathrm{hot} \mathrm{carrier} \mathrm{solar} \mathrm{cell} \mathrm{[8923-55]}$ Y. Feng, S. Lin, X. Wen, P. Zhang, S. Huang, S. Shrestha, M. Green, G. Conibeer, The Univ. of New South Wales (Australia)

$89231 \mathrm{~K}$ Solution processing of next-generation nanocrystal solar cells [8923-56] J. van Embden, A. S. R. Chesman, N. W. Duffy, E. Della Gaspera, J. J. Jasieniak, Commonwealth Scientific and Industrial Research Organisation (Australia)

8923 IL Optical properties and electron dynamics in carbon nanodots [8923-57] X. Wen, S. Huang, G. Conibeer, S. Shrestha, The Univ. of New South Wales (Australia); P. Yu, Y.-R. Toh, J. Tang, Academia Sinica (Taiwan)

\section{PLASMONICS II}

8923 1Q Optoplasmonics: hybridization in 3D [8923-62]

L. Rosa, G. Gervinskas, Swinburne Univ. of Technology (Australia) and Australian National Fabrication Facility (Australia); A. Žukauskas, M. Malinauskas, Vilnius Univ. (Lithuania); E. Brasselet, Lab. Ondes et Matière d'Aquitaine, CNRS, Univ. Bordeaux 1 (France); S. Juodkazis, Swinburne Univ. of Technology (Australia) and Australian National Fabrication Facility (Australia)

8923 IR Ultra-compact plasmonic nanoring laser [8923-63]

C.-W. Lee, Q. Wang, G. Singh, A*STAR - Data Storage Institute (Singapore); S.-T. Ho, Northwestern Univ. (United States) 
MEMS I

$89231 \mathrm{U} \quad$ Effect of surfaces on thermoelastic damping of nano-resonators [8923-66]

S. Dixit, M. M. Inamdar, D. N. Pawaskar, Indian Institute of Technology Bombay (India)

$89231 \mathrm{~V}$ Cryogenic optical profilometry for the calculation of coefficient of thermal expansion in thin films [8923-67]

K. L. Brookshire, R. Rafiei, M. Martyniuk, K. M. B. D. Silva, J. Bumgarner, R. W. Basedow, Y. Liu,

L. Faraone, The Univ. of Western Australia (Australia)

\section{PHOTONICS III}

$892321 \quad$ Measuring the electrical properties of semiconductor nanowires using terahertz conductivity spectroscopy (Invited Paper) [8923-73]

H. J. Joyce, Univ. of Oxford (United Kingdom) and Univ. of Cambridge (United Kingdom);

C. J. Docherty, C.-K. Yong, Univ. of Oxford (United Kingdom); J. Wong-Leung, Q. Gao,

S. Paiman, H. H. Tan, C. Jagadish, The Australian National Univ. (Australia); J. Lloyd-Hughes, Univ. of Warwick (United Kingdom); L. M. Herz, M. B. Johnston, Univ. of Oxford (United Kingdom)

892322 THz photomixer with a 40nm-wide nanoelectrode gap on low-temperature grown GaAs [8923-75]

G. Seniutinas, G. Gervinskas, Swinburne Univ. of Technology (Australia) and Australian National Fabrication Facility (Australia); E. Constable, Univ. of Wollongong (Australia); A. Krotkus, Ctr. for Physical Sciences and Technology (Lithuania); G. Molis, Teravil Ltd. (Lithuania); G. Valušis, Ctr. for Physical Sciences and Technology (Lithuania); R. A. Lewis, Univ. of Wollongong (Australia); S. Juodkazis, Swinburne Univ. of Technology (Australia) and Australian National Fabrication Facility (Australia)

$892324 \quad$ Extending device performance in photonic devices using piezoelectric properties [8923-77]

G. E. Triplett, Univ. of Missouri-Columbia (United States)

\section{METROLOGY/CHARACTERISATION}

892325 Sound of nano [8923-78]

J. Aylott, M. Clark, L. Marques, F. Perez-Cota, R. J. Smith, K. F. Webb, The Univ. of

Nottingham (United Kingdom)

\section{MICROFLUIDICS II}

8923 2B Microfluidic devices using thiol-ene polymers [8923-85]

S. J. M. C. Bou, A. V. Ellis, Flinders Univ. (Australia)

8923 2C A microfluidic platform to study the mechano sensational properties of ion channels [8923-86]

S. Baratchi, F. J. Tovar-Lopez, K. Khoshmanesh, M. Grace, W. Darby, P. Mclntyre, A. Mitchell, RMIT Univ. (Australia) 
$89232 \mathrm{~F} \quad$ Current density enhancement in inverted nanopyramid textured crystalline silicon solar cell using gold nanoparticles [8923-90]

S. Sivasubramaniam, D. Kumar, V. B. Golovko, M. M. Alkaisi, MacDiarmid Institute for Advanced Materials and Nanotechnology (New Zealand) and Univ. of Canterbury (New Zealand)

$89232 \mathrm{G}$ lon-beam and plasma etching of a conical-pores photonic crystal for thin-film solar cell [8923-91]

G. Gervinskas, L. Rosa, S. Juodkazis, Swinburne Univ. of Technology (Australia) and Australian National Fabrication Facility (Australia)

$89232 \mathrm{H} \quad$ Growth of CZTS by co-sputtering and sulfurization for solar cell applications [8923-92] N. Muhunthan, O. P. Singh, V. N. Singh, CSIR - National Physical Lab. (India)

$892321 \quad$ Potential of hafnium nitride for the hot carrier solar cell [8923-93]

S. Chung, S. Shrestha, H. Xia, N. Gupta, G. Conibeer, The Univ. of New South Wales (Australia)

\section{ELECTRONICS}

$89232 \mathrm{~A}$ A novel single dot test structure for determining specific contact resistivity [8923-102] Y. Pan, A. M. Collins, A. S. Holland, RMIT Univ. (Australia)

\section{PLASMONICS III}

$89232 R$

Plasmonics: the convergence between optics and electronics (Invited Paper) [8923-103] T. J. Davis, Commonwealth Scientific and Industrial Research Organisation (Australia) and Australian National Fabrication Facility (Australia)

$89232 S \quad$ Vanadium dioxide thickness effects on tunable optical antennas [8923-104]

S. K. Earl, T. D. James, The Univ. of Melbourne (Australia) and Australian National Fabrication Facility (Australia); R. E. Marvel, Vanderbilt Univ. (United States); D. E. Gomez, T. J. Davis, Australian National Fabrication Facility (Australia) and Commonwealth Scientific and Industrial Research Organisation (Australia); J. G. Valentine, Vanderbilt Univ. (United States); J. C. McCallum, The Univ. of Melbourne (Australia); R. F. Haglund Jr., Vanderbilt Univ. (United States); A. Roberts, The Univ. of Melbourne (Australia)

\section{MEMS II}

$89232 \mathrm{~V}$

A versatile instrumentation system for MEMS-based device optical characterization [8923-108]

R. Rafiei, R. W. Basedow, K. K. M. B. D. Silva, J. T. Gurusamy, J. R. Silva Castillo, D. K. Tripathi, J. M. Dell, L. Faraone, The Univ. of Western Australia (Australia) 
$89232 X \quad$ Buried picolitre fluidic channels in single-crystal diamond [8923-110] M. A. Strack, B. A. Fairchild, A. D. C. Alves, The Univ. of Melbourne (Australia); P. Senn, The Univ. of Melbourne (Australia) and Bionics Institute (Australia); B. C. Gibson, The Univ. of Melbourne (Australia) and RMIT Univ. (Australia); S. Prawer, The Univ. of Melbourne (Australia); A. D. Greentree, RMIT Univ. (Australia)

$89232 Y \quad H o w$ to fabricate robust microfluidic systems for a dollar [8923-11 1]

F. Lapierre, Commonwealth Scientific and Industrial Research Organisation (Australia) and Australian National Fabrication Facility (Australia); N. R. Cameron, Durham Univ. (United Kingdom); J. Oakeshott, T. Peat, Commonwealth Scientific and Industrial Research Organisation (Australia); Y. Zhu, Commonwealth Scientific and Industrial Research Organisation (Australia), Australian National Fabrication Facility (Australia), and Swinburne Univ. of Technology (Australia)

$89232 Z$ Modeling and fabrication of scale-like cantilever for cell capturing [8923-112]

B. Liu, J. Fu, M. Muradoglu, Monash Univ. (Australia)

892330 Nanoimprint lithography for microfluidics manufacturing [8923-113]

G. Kreindl, T. Matthias, EV Group (Austria)

SOLAR IV

892334 Plasmonic nanoparticles enhanced dye-sensitized solar cells [8923-117]

Q. XU, F. Liu, W. Meng, Y. Huang, Tsinghua Univ. (China)

892335 Ageing effects on plasmonic properties for solar cell applications [8923-1 18]

S. Pillai, Y. Yang, Y. Jiang, M. Green, The Univ. of New South Wales (Australia)

\section{Part Two}

\section{NANOMATERIALS IV}

892338 New efficient $\mathrm{p}$-n heterojunction of $\mathrm{BiOl}^{\mathrm{TiO}} \mathrm{Ti}_{2}$ nanotube arrays with enhanced visible-light photoelectrocatalytic activities [8923-121]

J. Liu, Hefei Univ. of Technology (China) and Anhui Key Lab. of Advanced Functional Materials and Devices (China); L. Ruan, J. Hu, Hefei Univ. of Technology (China); Y. Wang, Y. Wu, Hefei Univ. of Technology (China) and Anhui Key Lab. of Advanced Functional Materials and Devices (China

8923 3A Porous CNTs/chitosan composite with lamellar structure prepared by ice-templating [8923-123]

T. WU, J. Yan, Dalian Univ. of Technology (China) 
8923 3C Integrated microdroplet-based system for enzyme synthesis and sampling [8923-125] F. Lapierre, Commonwealth Scientific and Industrial Research Organisation (Australia) and Australian National Fabrication Facility (Australia); M. Best, R. Stewart, J. Oakeshott, T. Peat, Commonwealth Scientific and Industrial Research Organisation (Australia); Y. Zhu, Commonwealth Scientific and Industrial Research Organisation (Australia), Australian National Fabrication Facility (Australia), and Swinburne Univ. of Technology (Australia)

8923 3D A microfluidic device for studying cell signaling with multiple inputs and adjustable amplitudes and frequencies [8923-126]

Z. Ningsih, J. W. M. Chon, A. H. A. Clayton, Swinburne Univ. of Technology (Australia)

8923 3E Micro pore arrays in free standing cyclic olefin copolymer membranes: fabrication and surface functionalization strategies for in-vitro barrier tissue models [8923-127] M. Gel, Commonwealth Scientific and Industrial Research Organisation (Australia); S. Kandasamy, Australian National Fabrication Facility (Australia) and The Univ. of Melbourne (Australia); K. Cartledge, C. L. Be, D. Haylock, Commonwealth Scientific and Industrial Research Organisation (Australia)

\section{PHOTONICS IV}

$89233 \mathrm{H}$ Proposal of a Si based device for multiplexing conversion between PDM and MDM [8923-130]

M. Ye, Y. Yu, L. Xiang, B. Zou, X. Zhang, D. Huang, Huazhong Univ. of Science and Technology (China)

8923 3J Chiral elements and dual systems: towards the design of an omnidirectional optical active media [8923-132]

X. Vidal, Macquarie Univ. (Australia); X. Zambrana-Puyalto, Macquarie Univ. (Australia) and ARC Ctr. for Engineered Quantum Systems (Australia); A. F. Barbara, Macquarie Univ. (Australia); I. Fernandez-Corbaton, G. Molina-Terriza, Macquarie Univ. (Australia) and ARC Ctr. for Engineered Quantum Systems (Australia)

8923 3K Steady state design of photonic transistor to achieve a switching gain $>=3 \mathrm{~dB}$ [8923-133] V. Krishnamurthy, A*STAR - Data Storage Institute (Singapore); Y. Chen, National Univ. of Singapore (Singapore); S. T. Ho, Northwestern Univ. (United States)

\section{MATERIALS II}

8923 3P Non-intrusive tunable resonant microwave cavity for optical detected magnetic resonance of NV centres in nanodiamonds [8923-138] J.-M. Le Floch, The Univ. of Western Australia (Australia) and ARC Ctr. of Excellence for Engineered Quantum Systems (Australia); C. Bradac, T. Volz, ARC Ctr. of Excellence for Engineered Quantum Systems (Australia) and Macquarie Univ. (Australia); M. E. Tobar, The Univ. of Western Australia (Australia) and ARC Ctr. of Excellence for Engineered Quantum Systems (Australia); S. Castelletto, RMIT Univ. (Australia) 
FABRICATION III

$89233 \mathrm{~A}$ A fabrication method of out-of-plane stretchable and flexible electrodes based on PDMS [8923-140]

N. Chou, S. Kim, Gwangju Institute of Science and Technology (Korea, Republic of)

\section{PHOTONICS V}

8923 3T Chiral photonic crystals with four-fold symmetry: band structure and S-parameters of eight-fold intergrown Gyroid nets [8923-143]

M. Saba, Friedrich-Alexander-Univ. Erlangen-Nürnberg (Germany); M. D. Turner, M. Gu, Swinburne Univ. of Technology (Australia); K. Mecke, G. E. Schröder-Turk, Friedrich-

Alexander-Univ. Erlangen-Nürnberg (Germany)

\section{NANOMATERIALS V}

8923 3X Electrodeposition and characterization of Sb-doped ZnO nanostructures [8923-147] J. Liang, H. Su, Y. Wu, Hefei Univ. of Technology (China); S. Kao, C. Kuo, J.-A. Huang, National Cheng Kung Univ. (Taiwan)

POSTER SESSION

8923 3Y Fabrication of Fresnel zone plate lens in fused silica glass using femtosecond laser lithography technology [8923-3]

I.-B. Sohn, Gwangju Institute of Science and Technology (Korea, Republic of); M. S. Ahsan, Gwangju Institute of Science and Technology (Korea, Republic of) and Khulna Univ. (Bangladesh); Y. Noh, Gwangju Institute of Science and Technology (Korea, Republic of); H.-K. Choi, J.-T. Kim, Chosun Univ. (Korea, Republic of); M. J. Ko, Korea Institute of Industrial Technology (Korea, Republic of)

$89233 Z$ On-chip optical nano-scale displacement sensor [8923-107]

P. Wang, A. Michael, C. Kwok, The Univ. of New South Wales (Australia)

892343 Immobilization of lipase and keratinase on functionalized SBA-15 nanostructured materials [8923-152]

H. G. Le, T. A. VU, H. T. T. K. Tran, P. T. Dang, Vietnam Academy of Science and Technology (Viet Nam)

892344 Additive manufacturing of lab-on-a-chip devices: promises and challenges [8923-153] F. Zhu, RMIT Univ. (Australia); N. P. Macdonald, RMIT Univ. (Australia) and Univ. of Glasgow (United Kingdom); J. M. Cooper, Univ. of Glasgow (United Kingdom); D. Wlodkowic, RMIT Univ. (Australia)

892345 A high-throughput lab-on-a-chip interface for zebrafish embryo tests in drug discovery and ecotoxicology [8923-154]

F. Zhu, J. Akagi, RMIT Univ. (New Zealand); C. J. Hall, K. E. Crosier, P. S. Crosier, The Univ. of Auckland (New Zealand); P. Delaage, Trophos SA (France); D. Wlodkowic, RMIT Univ.

(Australia) 
892346 Immobilization of zebrafish larvae on a chip-based device for environmental scanning electron microscopy (ESEM) imaging [8923-155]

J. Akagi, The Univ. of Auckland (Australia); C. J. Hall, K. E. Crosier, P. S. Crosier, The Univ. of Auckland (New Zealand); D. Wlodkowic, RMIT Univ. (Australia)

892347 Microfluidic EmbryoSort technology: towards in flow analysis, sorting and dispensing of individual vertebrate embryos [8923-156]

N. M. Fuad, D. Wlodkowic, RMIT Univ. (Australia)

8923 4A Eye trackers in an oculary clinical setting [8923-159]

M. M. Shahimin, Univ. Kebangsaan Malaysia (Malaysia); M. M. Shahimin, Univ. Malaysia Perlis (Malaysia)

8923 4B Performance characteristics of valveless and cantilever-valve micropump [8923-160] A. F. M. Shukur, N. Sabani, B. N. Taib, M. A. M. Azidin, M. M. Shahimin, Univ. Malaysia Perlis (Malaysia)

8923 4C The application and quantitative testing of 150 million pixel CMOS image sensor [8923-161] X. Gong, Shanghai Institute of Technical Physics (China) and The Graduate Univ. of Chinese Academy of Sciences (China); F. Chen, Shanghai Institute of Technical Physics (China); S. Huang, X. Su, Y. Dong, Shanghai Institute of Technical Physics (China) and The Graduate Univ. of Chinese Academy of Sciences (China)

8923 4D Optimization of physical parameters of 'injected' metal electrodes for capacitively coupled contactless conductivity detection on poly(dimethylsiloxane) microchips [8923-162]

L. D. Thredgold, D. A. Khodakov, A. V. Ellis, C. E. Lenehan, Flinders Univ. (Australia)

8923 4E Effect of mesh element type of Finite Element Model (FEM) on unimorph cantilever vibration [8923-163]

H. Aris, La Trobe Univ. (Australia) and Univ. Malaysia Perlis (Malaysia); D. Fitrio, J. Singh, La Trobe Univ. (Australia)

8923 4F Metal-oxide-semiconductor field-effect transistors operated by surface plasmon polaritons [8923-164]

T. Aihara, A. Takeda, M. Fukuhara, Y. Ishii, M. Fukuda, Toyohashi Univ. of Technology (Japan)

8923 4G Sensitivity improvement of Schottky-type plasmonic detector [8923-165]

A. Takeda, Toyohashi Univ. of Technology (Japan); T. Aihara, M. Fukuhara, Toyohashi Univ. of Technology (Japan) and Japan Society for the Promotion of Science (Japan); Y. Ishii, M. Fukuda, Toyohashi Univ. of Technology (Japan)

8923 4l A method for evaporating silicon to form low dimensional Si lattice structures [8923-167]

D. C. Ng, National ICT Australia (Australia) and The Univ. of Melbourne (Australia);

K. Ganesan, A. Stacey, E. Skafidas, The Univ. of Melbourne (Australia)

$89234 \mathrm{~J} \quad$ Catalytic pyrolysis of biomass by novel nanostructured catalysts [8923-168]

P. T. Dang, H. G. Le, G. T. T. Pham, H. T. M. Vu, K. T. Nguyen, C. D. Dao, G. H. Le,

T. T. T. Hoang, H. T. K. Tran, Q. K. Nguyen, T. A. Vu, Vietnamese Academy of Science and Technology (Viet Nam) 
8923 4K High-speed camera observation of multi-component droplet coagulation in an ultrasonic standing wave field [8923-169]

M. Reißenweber, S. Krempel, G. Lindner, Hochschule für angewandte Wissenschaften und Künste Coburg (Germany)

$89234 \mathrm{~L} \quad$ Fabrication and replication of micro-optical structures for growth of GaN-based light emitting diodes [8923-170]

G. Gervinskas, G. Seniutinas, Swinburne Univ. of Technology (Australia) and Australian National Fabrication Facility (Australia); A. Vijayakumar, S. Bhattacharya, Indian Institute of Technology Madras (India); E. Jelmakas, A. Kadys, R. Tomašiūnas, Vilnius Univ. (Lithuania); S. Juodkazis, Swinburne Univ. of Technology (Australia) and Australian National Fabrication Facility (Australia)

$89234 \mathrm{M}$ The NUC and blind pixel eliminating in the DTDI application [8923-171]

$X$. Su, Shanghai Institute of Technical Physics (China) and Univ. of Chinese Academy of Sciences (China); F. Chen, Shanghai Institute of Technical Physics (China); S. Pan,

X. Gong, Y. Dong, Shanghai Institute of Technical Physics (China) and Univ. of Chinese Academy of Sciences (China)

892340 A waveguide based microfluidic application [8923-174]

N. S. Taheri, P. Chan, J. R. Friend, L. Yeo, RMIT Univ. (Australia)

8923 4P Long-wavelength infrared Fabry-Perot etalon for multi-spectral thermal imaging [8923-175] H. Mao, A. J. Keating, D. Silva, J. M. Dell, L. Faraone, The Univ. of Western Australia (Australia)

$89234 Q \quad$ Targeted sacrificial layer etching for MEMS release using microfluidic channels [8923-176] B. C. Cheah, A. J. Keating, J. M. Dell, The Univ. of Western Australia (Australia)

$89234 R \quad$ Dark-field microspectroscopic analysis of gold nanorods in spiral Ganglion neurons [8923-177]

J. Yong, W. G. A. Brown, Swinburne Univ. of Technology (Australia); K. Needham, B. A. Nayagam, The Univ. of Melbourne (Australia); A. Yu, S. L. McArthur, P. R. Stoddart, Swinburne Univ. of Technology (Australia)

$89234 \mathrm{~S} \quad$ Nanocrystallic thin films statistical structural analysis by the automatic image processing [8923-178]

M. Wielgus, Z. Sunderland, D. Koguciuk, K. Patorski, Warsaw Univ. of Technology (Poland); G. Słowik, Univ. of Maria Curie-Sklodowska (Poland)

$89234 \mathrm{~T} \quad$ Formation of cylindrical micro-lens array in fused silica glass using laser irradiations [8923-179]

H.-K. Choi, Gwangju Institute of Science and Technology (Korea, Republic of) and Chosun Univ. (Korea, Republic of); M. S. Ahsan, Gwangju Institute of Science and Technology (Korea, Republic of) and Khulna Univ. (Bangladesh); D. Yoo, I.-B. Sohn, Y.-C. Noh, Gwangju Institute of Science and Technology (Korea, Republic of); J. T. Kim, Chosun Univ. (Korea, Republic of); D. Jung, J. H. Kim, Chonnam National Univ. (Korea, Republic of)

$89234 \mathrm{U}$ Micro flexible robot hand using electro-conjugate fluid [8923-180]

S. Ueno, K. Takemura, Keio Univ. (Japan); S. Yokota, Tokyo Institute of Technology (Japan);

K. Edamura, New Technology Management Co., Ltd. (Japan) 
$89234 \mathrm{~V} \quad$ Effect of the subsidiary electrode in a newly developed source lens structure of the microcolumn [8923-181]

T.-S. Oh, D.-W. Kim, H. S. Kim, Sun Moon Univ. (Korea, Republic of); W. K. Jang, Hanseo Univ. (Korea, Republic of)

$89234 \mathrm{~W}$ Shape optimization of electrostatically driven microcantilevers using simulated annealing to enhance static travel range [8923-182]

R. R. Trivedi, Indian Institute of Technology Bombay (India); M. M. Joglekar, Indian Institute of Technology Roorkee (India); R. P. Shimpi, D. N. Pawaskar, Indian Institute of Technology Bombay (India)

$89234 \mathrm{X}$ Optical and thermal characterization on micro-optical elements made by femtosecond laser writing [8923-183]

R. Buividas, Swinburne Univ. of Technology (Australia) and Australian National Fabrication Facility (Australia); V. Mizeikis, Shizuoka Univ. (Japan); G. Kiršanske, A. Žukauskas,

M. Malinauskas, Vilnius Univ. (Lithuania); T. Murayama, Tokyo Institute of Technology

(Japan); Y. Hikima, Kyoto Univ. (Japan); J. Morikawa, Tokyo Institute of Technology

(Japan); S. Juodkazis, Swinburne Univ. of Technology (Australia) and Australian National Fabrication Facility (Australia)

$89234 Z$ Governing equations for electro-conjugate fluid flow [8923-185]

K. Hosoda, K. Takemura, K. Fukagata, Keio Univ. (Japan); S. Yokota, Tokyo Institute of Technology (Japan); K. Edamura, New Technology Management Co., Ltd (Japan)

892350 Micro-structured surfaces for algal biofilm growth [8923-186]

S. Sathananthan, S. N. Genin, J. S. Aitchison, D. G. Allen, Univ. of Toronto (Canada)

$892351 \quad$ Anti-reflection properties of spherical top nanowire arrays for solar cell applications [8923-187]

F. Tao, J. Chen, F. He, H. Zhou, Peking Univ. Shenzhen Graduate School (China)

892352 Development of a multi-electrode system for non-destructive and contactless wafer evaluation [8923-190]

J. Ndagijmana, Y. Soh, J. Fukashi, K. Kobayashi, M. Furuta, H. Kubota, Kumamoto Univ. (Japan)

892353 Development of a multi-flash lamp in pulse photo conductivity method [8923-191] J. Fukashi, J. Ndagijimana, Y. Soh, K. Kobayashi, M. Furuta, H. Kubota, Kumamoto Univ. (Japan)

892356 Investigating extremely low resistance ohmic contacts to silicon carbide using a novel test structure [8923-194]

Y. Pan, A. M. Collins, F. Algahtani, P. W. Leech, G. K. Reeves, RMIT Univ. (Australia);

P. Tanner, Griffith Univ. (Australia); A. S. Holland, RMIT Univ. (Australia)

892357 Effects of low power microwave radiation on biological activity of Collagenase enzyme and growth rate of S. Cerevisiae yeast [8923-195]

H. S. Alsuhaim, V. Vojisavljevic, E. Pirogova, RMIT Univ. (Australia)

892359 Improved geometrical design of the circular transmission line model ohmic contact test structure [8923-197]

A. Collins, Y. Pan, A. Holland, RMIT Univ. (Australia) 
$89235 \mathrm{~A}$ Optimizing the thermal budget for forming of nickel germanide on crystalline germanium [8923-200]

F. Algahtani, RMIT Univ. (Australia); M. Blackford, Australian Nuclear Science and Technology Organisation (Australia); E. Pirogova, A. S. Holland, RMIT Univ. (Australia)

8923 5B Detection of harmful algal bloom causing microalgae using covalently immobilised capture oligonucleotide probes on glass and poly(dimethylsiloxane) surfaces [8923-201] K. L. Bruce, A. V. Ellis, S. C. Leterme, D. A. Khodakov, C. E. Lenehan, Flinders Univ. (Australia)

8923 5C Surface acoustic streaming in microfluidic system for rapid multicellular tumor spheroids generation [8923-202]

L. AlHasan, A. Qi, RMIT Univ. (Australia); A. Al-Aboodi, Monash Univ. (Australia); A. Rezk, R. R. Shilton, RMIT Univ. (Australia); P. P. Y. Chan, J. Friend, RMIT Univ. (Australia) and Australian National Fabrication Facility (Australia); L. Yeo, RMIT Univ. (Australia)

8923 5D Four point probe geometry modified correction factor for determining resistivity [8923-203] F. Algahtani, K. B. Thulasiram, RMIT Univ. (Australia); N. F. M. Nasir, Univ. Malaysia Perlis (Malaysia); A. S. Holland, RMIT Univ. (Australia)

8923 5E Modelling and fabrication of thermally actuated micropores for biological sensing [8923-204]

H. L. Lee, B. Liu, J. Fu, Monash Univ. (Australia)

$89235 \mathrm{~F}$ Assessment of $\mathrm{GeB}$ doped $\mathrm{SiO}_{2}$ optical fiber for the application of remote radiation sensing system [8923-205]

A. Alawiah, M. M. Fadhli, Multimedia Univ. (Malaysia); S. Bauk, Univ. Sains Malaysia (Malaysia); H. A. Abdul-Rashid, Multimedia Univ. (Malaysia); M. J. Maah, Univ. of Malaya (Malaysia)

8923 5G Hydrophobicity studies of polymer thin films with varied CNT concentration [8923-206] N. H. M. Rodzi, M. M. Shahimin, P. Poopalan, B. Man, M. N. M. Nor, Univ. Malaysia Perlis (Malaysia)

$89235 \mathrm{H}$ Investigation of amorphisation of germanium using modeling and experimental processes [8923-207]

S. Almalki, F. Algahtani, RMIT Univ. (Australia); M. Blackford, Australian Nuclear Science and Technology Organisation (Australia); M. S. Alnassar, RMIT Univ. (Australia); B. C. Johnson, J. C. McCallum, The Univ. of Melbourne (Australia); A. S. Holland, RMIT Univ. (Australia)

$89235 \mathrm{P}$ Preparation of $\mathrm{Cu}_{2} \mathrm{O} / \mathrm{TiO}_{2}$ nanotube heterojunction arrays with enhanced photoelectrocatalysis performance [8923-208]

J. Zhang, Y. Wang, T. Shen, H. Bian, X. Shu, Y. WU, Hefei Univ. of Technology (China);

Z. Chen, Nanyang Technological Univ. (Singapore)

8923 5 Green synthesis of silver nanoparticles as antibacterial agent using Rhodomyrtus tomentosa acetone extract [8923-209]

S. P. Voravuthikunchai, J. Chorachoo, Prince of Songkla Univ. (Thailand); L. Jaiswal, RMIT Univ. (Australia); S. Shankar, Prince of Songkla Univ. (Thailand)

$89235 \mathrm{~K}$ Spectroscopic modeling of water molecule [8923-210]

R. I. Danylo, B. A. Okhrimenko, National Taras Shevchenko Univ. of Kyiv (Ukraine)

Author Index 


\title{
Conference Committee
}

\author{
Conference Chair \\ James Friend, RMIT University (Australia) \\ Program Chair
}

H. Hoe Tan, The Australian National University (Australia)

Organising Committee

Brian Abbey, La Trobe University (Australia)

Peggy P. Chan, RMIT University (Australia)

Wenlong Cheng, Monash University (Australia)

Christina Cortez-Jugo, Monash University (Australia)

Timothy J. Davis, Commonwealth Scientific and Industrial Research Organisation (Australia)

Daniel Gomez, The University of Melbourne (Australia)

Stefan Harrer, IBM Research (Australia)

Dwayne Kirk, Melbourne Center for Nanofabrication (Australia)

Mainak Majumder, Monash University (Australia)

Gareth Moorhead, Commonwealth Scientific and Industrial Research Organisation (Australia)

Paul Mulvaney, The University of Melbourne (Australia)

Yonggang Zhu, Commonwealth Scientific and Industrial Research

Organisation (Australia)

Special Committee Members

Saulius Juodkazis, Swinburne University of Technology (Australia)

Min Gu, Swinburne University of Technology (Australia)

Program Committee

Fumihito Arai, Tohoku University (Japan)

Andrea M. Armani, The University of Southern California (United States)

Zhanghai Chen, Fudan University (Japan)

Anna Fontcuberta i Morral, Ecole Polytechnique Fédérale de Lausanne (Switzerland)

Sajeev John, University of Toronto (Canada)

Adrian J. Keating, The University of Western Australia (Australia)

Alexander M. Korsunsky, University of Oxford (United Kingdom)

Sanjay Krishna, The University of New Mexico (United States)

Sebastian Lourdudoss, Royal Institute of Technology (Sweden)

Scott R. Manalis, MIT Media Laboratory (United States)

Dragomir N. Neshev, The Australian National University (Australia) 
Matteo Pasquali, Rice University (United States)

Zuzanna Siwy, University of California, Irvine (United States)

Leigh M. Smith, University of Cincinnati (United States)

\section{Session Chairs}

1 Fabrication I

Adam Mechler, La Trobe University (Australia)

2 Solar I

Sudha Mokkapati, The Australian National University (Australia)

3 Nanomaterials I

H. Hoe Tan, The Australian National University (Australia)

4 Bio I

Christina Cortez-Jugo, Monash University (Australia)

5 Photonics I

Lei Zhou, Fudan University (China)

6 Materials I

Dan Li, Monash University (Australia)

7 Microfluidics I

Michel Versluis, Universiteit Twente (Netherlands)

8 Plasmonics 1

Sudha Mokkapati, The Australian National University (Australia)

9 Nanomaterials II

Wenlong Cheng, Monash University (Australia)

10 Bio II

Andrea M. Armani, The University of Southern California (United States)

11 Photonics II

Peter J. Reece, The University of New South Wales (Australia)

12 Solar II

Evelyne Gil, Université Blaise Pascal (France)

13 Fabrication II

Dwayne D. Kirk, Melbourne Center for Nanofabrication (Australia)

14 Plasmonics II

Arnan Mitchell, RMIT University (Australia) 
15 MEMS I

Adrian Keating, The University of Western Australia (Australia)

16 Bio III

Dan V. Nicolau, McGill University (Canada)

17 Photonics III

Lan Fu, The Australian National University (Australia)

18 Metrology/Characterisation

Gareth F. Moorhead, Commonwealth Scientific and Industrial Research Organisation (Australia)

19 Microfluidics II

Lydia L. Sohn, University of California, Berkeley (United States)

20 Solar III

Lan Fu, The Australian National University (Australia)

21 Nanomaterials III

Mainak Majumder, Monash University (Australia)

22 Electronics

Hannah J. Joyce, University of Oxford (Australia)

23 Plasmonics III

Kylie R. Catchpole, The Australian National University (Australia)

24 MEMS II

Weidong Zhou, The University of Texas at Arlington (United States)

25 Microfludics III

James Friend, RMIT University (Australia)

26 Solar IV

Timothy J. Davis, Commonwealth Scientific and Industrial Research Organisation (Australia)

27 Nanomaterials IV

Michael S. Fuhrer, Monash University (Australia)

28 Bio IV

Stefan Harrer, IBM Research (Australia)

29 Photonics IV

Masaya Notomi, NTT Basic Research Laboratories (Japan) 
30 Materials II

Takeshi Morita, The University of Tokyo (Japan)

31 Fabrication III

Rosie Hicks, Australian National Fabrication Facility (Australia)

32 Photonics $V$

Leigh M. Smith, University of Cincinnati (United States)

33 Nanomaterials $V$

Takeshi Morita, The University of Tokyo (Japan) 


\title{
Nano-architecture: creating complex surface structures using supramolecular self-assembly of tripeptides
}

\author{
Adam Mechler*a, Rania Seoudi, Mark P. Del Borgo ${ }^{\mathrm{b}}$, Marie-Isabel Aguilar ${ }^{\mathrm{b}}$, Patrick Perlmutter ${ }^{\mathrm{c}}$ \\ ${ }^{a}$ School of Molecular Sciences, La Trobe University, Australia; ${ }^{b}$ Department of Biochemistry \& \\ Molecular Biology, Monash University, Australia; ${ }^{\mathrm{C} S c h o o l}$ of Chemistry, Monash University, \\ Australia
}

Keywords: self-assembly, supramolecular recognition, artificial silk, unnatural $\beta$-peptide

\begin{abstract}
Here we report on using small unnatural helical beta peptides to form higher order geometries. These peptides are known to self-assemble by supramolecular recognition, via a unique 3-point H-bonding motif. This self-assembly pattern leads to unprecedented head-to-tail self-assembly, thus continuing the intramolecular helix into a fibrous superstructure. The smallest peptide still capable of self-assembly had a sequence of only three beta amino acids. We demonstrated a hierarchical self-assembly process, which can be designed to form macroscopic silk-like threads as well as complex nanometer scale surface structures. We have achieved radial as well as parallel geometries. Both the synthesis and the derivatization of the fibres is relatively straigthforward, making this platform technology ideally suited for the highly exacting requirements of materials science.

*a.mechler@latrobe.edu.au
\end{abstract}

\section{INTRODUCTION}

Until recently, nanotechnology has been dominated by top down nanofabrication. While a plethora of bottom-up approaches have been proposed, the ability to create patterns in a spatially consistent manner is still a challenge ${ }^{[1,2]}$. The most success has been achieved using biomaterials such as peptide amphiphiles ${ }^{[3]}$. However, the limitations of the amphiphile self-assembly - the low specificity and selectivity of the self-assembly motif, and the dependence on an aqueous environment - still does not allow for the design of hierarchical structures. Supramolecular self-assembly offers the means to overcome the existing limitations and design new functional nanomaterials. The specificity and selectivity offered by supramolecular recognition minimizes defects, while the geometrically optimized physical bonding networks introduce high strength. In recent work ${ }^{[4]}$ we reported the design of a unique supramolecular self-assembly motif for the head-to-tail assembly of small, inherently helical unnatural beta peptides, effectively turning the self-assembled structure into a continuation of the intramolecular helix. These helices have a perfect pitch, with exactly three amino acids per turn, and thus the residues are aligned along the helix. We described how these core fibrils bundled to form microscopic and macroscopic threads. Here we describe the formation of complex geometries based on the same principle.

\section{EXPERIMENTAL}

MATERIALS. Spectrophotometric grade solvents were purchased from Sigma Aldrich. Peptides were synthesized as described ${ }^{[4]}$ using standard solid state synthetic methods. Beta amino acids were purchased from GL Biochem. Peptide solutions were freshly prepared in methanol, isopropanol, acetone and chloroform solvents by dissolving $1 \mathrm{mg}$ of the lyophylized peptide in $1 \mathrm{ml}$ of each solvent separately. The solutions were vortexed for $3 \mathrm{~min}$, and then incubated for at 
least $24 \mathrm{hr}$ before use. Peptide solutions were drop cast onto mica surface, dried under $\mathrm{N}_{2}$, aged overnight and imaged with AFM.

ATOMIC FORCE MICROSCOPY. Deposits were characterized using atomic force microscopy (AFM) with an Ntegra system (NT-MDT, Russia), in scan-by-sample configuration. NSG30 NT-MDT silicon cantilevers were used with a typical spring constant of $72 \mathrm{~N} \mathrm{~m}^{-1}$ and a nominal tip radius of $10 \mathrm{~nm}$. All samples were imaged under ambient conditions using semi-contact (tapping) mode at 512x512 pixel resolution and $0.5-1 \mathrm{~Hz}$ scan rate.

\section{RESULTS AND DISCUSSION}

The AFM images show fibrous material with a geometry that suggest a well defined one dimensional self-assembly into fibres (figure 1). It is apparent that the smaller fibres twist into consecutively larger structures in a hierarchical manner. Thus the self-assembly follows two motifs. The supramolecular self-assembly provides the fibrous core structure while adhesion between the fibres leads to the formation of branched hierarchical structures.

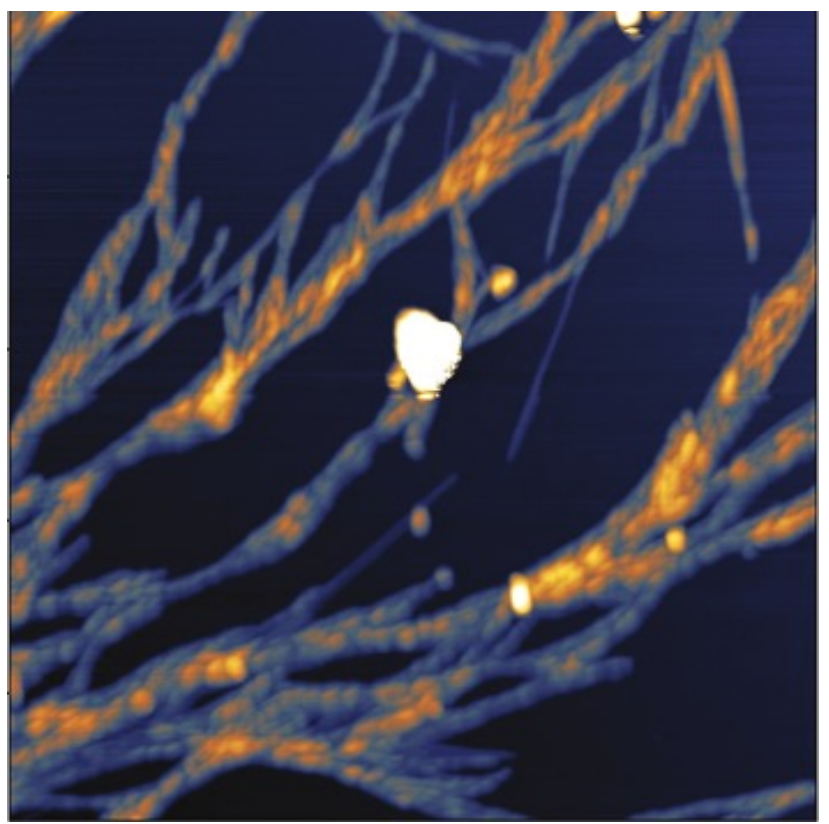

Figure 1 ac- $\beta$ L $\beta I \beta A$ on mica surface, imaged by AFM. The scale is $10 \mu \mathrm{m}$. The peptide was dissolved in methanol and mixed with isopropanol for deposition. Typical heights of fibres are 20-30 nm

In the second example, the structures have been radial in appearance (figure 2). In this case the self-assembly process was aborted by quick drying. Imaging revealed the presence of non-assembled material that has coated the surface; the layer is viscous and it causes high probe adhesion to the surface, further confirming its amorphous nature. Since the selfassembly did not proceed, here the initial stages are visible. The fibre nucleation happens simultaneously at several places, and fibre growth proceeds from these sites initially in a distorted radial geometry, forming twisted branches in a hierarchically decreasing geometry from the center outwards.

The major advantage of this process over amphiphilic self-assembly is that the two motifs are distinctly different in their specificity and selectivity, and are responsible for two different geometrical trends. Thus, while it is possible to control the geometry to some extent by the balance of hydrophobic and repulsive interactions in the case of amphiphilic self- 


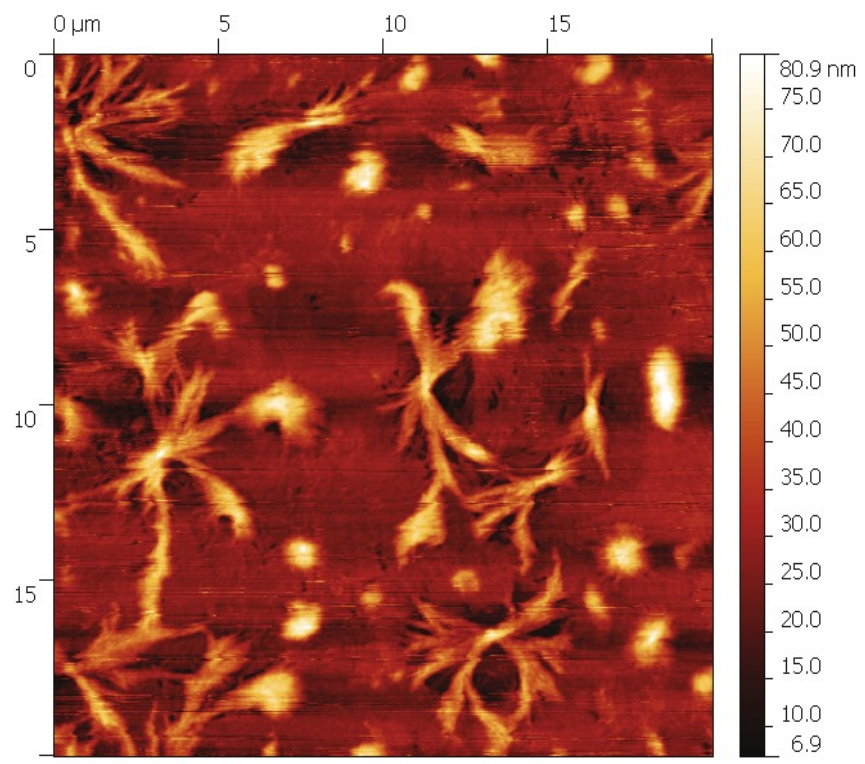

Figure 2 Peptides were deposited from methanol with an addition of isopropanol. Self-assembly was aborted via quick drying. The nucleation sites of fibre formation are visible as radial structures.

assembly $^{[5]}$, the design presented here is superior in that a highly specific and selective supramolecular self-assembly motif provides the core structures.

\section{CONCLUSIONS}

Fibrous surface structures have been created using supramolecular self-assembly of small unnatural $\beta$ peptides. These surface structures might be radial or parallel. The structures are based on a 3-point H-bonding motif that implements head-to-tail self-assembly, in essence a continuous helical structure, of small non-amphiphilic peptides. The structure offers itself for easy functionalization with three well-defined functional sites in a trigonal geometry. Thus it is a platform technology for applications that rely on the delivery of complex payload in a spatially controlled geometry.

\section{REFERENCES}

[1] Zhang, S. G. "Fabrication of novel biomaterials through molecular self-assembly". Nature Biotechnology 21, 1171-1178, doi:10.1038/nbt874 (2003)

[2] Lowik, D. \& van Hest, J. C. M. "Peptide based amphiphiles". Chemical Society Reviews 33, 234-245, doi:10.1039/b212638a (2004)

[3] Cui, H., Webber, M. J. \& Stupp, S. I. "Self-Assembly of Peptide Amphiphiles: From Molecules to Nanostructures to Biomaterials" Biopolymers 94, 1-18, doi:10.1002/bip.21328 (2010).

[4] Del Borgo, M. P. et al. "Supramolecular Self-Assembly of N-Acetyl-Capped beta-Peptides Leads to Nano- to Macroscale Fiber Formation" Angewandte Chemie-International Edition 52, 8266-8270, doi:10.1002/anie.201303175 (2013).

[5] Versluis, F., Marsden, H. R. \& Kros, A. "Power struggles in peptide-amphiphile nanostructures" Chemical Society Reviews 39, 3434-3444, doi:10.1039/b919446k (2010) 
Proc. of SPIE Vol. $8923892301-24$

Downloaded From: https://www.spiedigitallibrary.org/conference-proceedings-of-spie on 26 Apr 2023 Terms of Use: https://www.spiedigitallibrary.org/terms-of-use 


\title{
Synthesis and electrochemical characterization of novel MOF-reduced graphene oxide composites
}

\author{
P. Chakraborty Banerjee ${ }^{1,2}$, Rechana CNR ${ }^{1,2}$, D. Lobo ${ }^{1,2}$, Morteza Miansari ${ }^{1,2}$ and Mainak \\ Majumder ${ }^{1,2 *}$ \\ ${ }^{1}$ Nanoscale Science and Engineering Laboratory (NSEL), Monash University, Clayton, Victoria, \\ VIC 3800, Australia \\ ${ }^{2}$ Mechanical and Aerospace Engineering, Monash University, Clayton, Victoria, VIC 3800, \\ Australia
}

Recently great interest has been drawn towards carbon materials that include graphene and similar 2D materials owing to their unique structural and physical properties ${ }^{1}$. Graphene with its flat $2 \mathrm{D}$ structure possess reasonably large surface area and good electrical conductivity. These properties could specifically tune in combination with the other related materials by forming nanocomposites and thereby imparting novel as well as improved properties compared to their parent materials. Another class of materials, Metal-organic frameworks or MOFs are emerging as very interesting porous materials with extremely large internal surface area and tunable chemical properties. These materials are new generation porous crystalline materials suitably formed by the co-ordination of organic - inorganic moieties in a well-defined pattern. The organic linkers connected with metal centres provide them with extremely high surface area and ability to introduce variable functional groups. However, MOFs are generally insulators. It can be hypothesized that a combination of MOF with graphene will generate materials with large surface area and high electrical conductivity, which in turn may lead to the development of efficient supercapacitors. A few studies ${ }^{2-7}$ have investigated the MOF-carbon systems with the main focus towards materials for gas separation, gas storage and supercapacitor applications. Jahan et al. ${ }^{6}$ reported the structure directing role of reduced graphene oxide (RGO) in the synthesis of MOF5. Petit et al. ${ }^{7}$ synthesized several different novel composites based on a copper based MOF (HKUST-1) and RGO and studied the reactive adsorption of ammonia in order to characterize the mechanisms of the retention process. Guo et al. ${ }^{2}$ reported that composites synthesized using RGO and a platinum based MOF can be modified further to perform bioanalysis, biocatalysis and environmental monitoring. However, to the authors best knowledge there has not been any study to investigate whether MOF and RGO based composite materials can be used as supercapacitors. Hence, in the present study we have synthesized MOF5 and RGO composites with varying amounts of RGO and have investigated the electrochemical responses of these materials in $1 \mathrm{M}$ sodium sulphate $\left(\mathrm{Na}_{2} \mathrm{SO}_{4}\right)$ electrolyte.

In this study, we have synthesized three different MOF5-RGO composites with $3 \%, 5 \%$ and $7 \%$ of RGO content using a DMF approach of MOF synthesis ${ }^{8}$. X-ray diffraction (XRD) and Raman spectra were performed to analyse the chemical nature of MOF composites. Although the XRD spectra suggested that the inherent cubical symmetry of MOF5 was absent in case of the composites containing 3\% and 5\% RGO, it was present in case of the composite containing $7 \%$ of RGO. This can be attributed to the fact that the higher content of RGO in the composite containing $7 \%$ of RGO maintains the cubical symmetry of MOF5 by wrapping moisture sensitive ${ }^{9}$ MOF surface. This was further supported by the scanning electron micrographs (SEM) of the morphology of the composites containing 7\% RGO. Raman spectra of all the composites $(3 \%, 5 \%$ and $7 \%$ ) had peaks corresponding to both RGO and MOF5. The BET surface area of the composite containing $7 \%$ RGO $\left(1400 \mathrm{~m}^{2} / \mathrm{g}\right)$ was about two orders of magnitude higher than the other two composites $(3 \%$ and $5 \%)$. The electrical conductivity of the composite materials increased with increasing RGO content and the maximum electrical conductivity was observed in case of the composite containing 7\% RGO. The electrochemical characterization of all the composites was performed in a three electrode electrochemical cell (composites were used as the working electrode, platinum mesh as the counter electrode and saturated calomel electrode as the reference electrode) in $1 \mathrm{M} \mathrm{Na}_{2} \mathrm{SO}_{4}$ using a Biologic VSP potentiostat. The cyclic voltametry (performed in the range of 0-0.5 V vs SCE at a scan rate of $20 \mathrm{mV} / \mathrm{s}$ ) and the galvanostatic charge-discharge (performed at a constant current of $0.5 \mathrm{~A} / \mathrm{g}$ in the potentials range of 0-1 V vs SCE) showed that the specific capacitance of the composite materials increased with increasing RGO content. The maximum specific capacitance was obtained in case of the composite containing $7 \%$ RGO and was about 5 times better than only RGO. The higher specific capacitance obtained in case of the composite containing $7 \%$ RGO can be attributed to the fact that this composite material had the combination of the highest surface area and the highest electrical conductivity. The cyclability of the composites was evaluated for 1000 cycles using the galvanostatic charge- 
discharge experiments. The specific capacitance retention of the composite containing $7 \%$ RGO was significantly high (80\%) even after 1000 cycles.

\section{References:}

1 Li, X. S. et al. Large-Area Synthesis of High-Quality and Uniform Graphene Films on Copper Foils. Science 324, 1312-1314, doi:DOI 10.1126/science.1171245 (2009).

2 Guo, Y., Han, Y., Shuang, S. \& Dong, C. Rational synthesis of graphene-metal coordination polymer composite nanosheet as enhanced materials for electrochemical biosensing. Journal of Materials Chemistry 22, 1316613173, doi:10.1039/c2jm31997g (2012).

3 Kumar, N. A. et al. Polyaniline-Grafted Reduced Graphene Oxide for Efficient Electrochemical Supercapacitors. ACS Nano 6, 1715-1723, doi:10.1021/nn204688c (2012).

4 Xiang, Z. P., X;Cheng, X;Li, XJ;Cao, DP. CNT@Cu(3)(BTC)(2) and Metal-Organic Frameworks for Separation of CO(2)/CH(4) Mixture. J PHYS CHEM C 115(40), 19864-19871 (2011).

5 Li-Feng Chen, X.-D. Z., Hai-Wei Liang, Mingguang Kong, Qing-Fang Guan, Ping Chen , Zhen-Yu Wu , and Shu-Hong Yu Synthesis of Nitrogen-Doped Porous Carbon Nanofibers as an Efficient Electrode Material for Supercapacitors

ACS NANO 6, 7092-7102 (2012).

6 Jahan, M., Bao, Q., Yang, J.-X. \& Loh, K. P. Structure-Directing Role of Graphene in the Synthesis of Metal-Organic Framework Nanowire. Journal of the American Chemical Society 132, 14487-14495, doi:10.1021/ja105089w (2010).

7 Petit, C., Mendoza, B. \& Bandosz, T. J. Reactive Adsorption of Ammonia on Cu-Based MOF/Graphene Composites. Langmuir 26, 15302-15309, doi:10.1021/la1021092 (2010).

8 Saha, D., Deng, S. \& Yang, Z. Hydrogen adsorption on metal-organic framework (MOF-5) synthesized by DMF approach. Journal of Porous Materials 16, 141-149, doi:10.1007/s10934-007-9178-3 (2009).

9 Greathouse, J. A. \& Allendorf, M. D. The Interaction of Water with MOF-5 Simulated by Molecular Dynamics. Journal of the American Chemical Society 128, 10678-10679, doi:10.1021/ja063506b (2006). 


\title{
Tunable reduction and amorphisation of graphene oxide films by focused ion beam irradiation
}

\author{
Derrek E. Lobo ${ }^{\mathrm{a}, \mathrm{b}}$, Jing Fu ${ }^{\mathrm{b}}$, Thomas Gengenbach ${ }^{\mathrm{c}}$, Mainak Majumder ${ }^{\mathrm{a}, \mathrm{b}}$ \\ ${ }^{\mathrm{a}}$ Nanoscale Science and Engineering Laboratory (NSEL) and ${ }^{\mathrm{b}}$ Mechanical and Aerospace \\ Engineering, Monash University, Clayton, \\ ${ }^{\mathrm{c}}$ CSIRO Materials Science and Engineering, Bayview Avenue, Clayton, Victoria,
}

\begin{abstract}
Graphene has risen to prominence as a scientifically intriguing material with tremendous potential, making its fabrication a key research area. An intriguing and innovative route to its synthesis is the use of focused ion beam irradiation to achieve spatially patterned reduction of graphene oxide. Here we explore the sensitivity of this approach, analysing the key parameter of ion fluence through a systematic study, ranging from $0-0.204 \mathrm{nC} / \mu \mathrm{m}^{2}$. We characterize the regimes of preferential reduction and amorphisation, and analyzing changes in the materials bulk conductivity and Raman spectra, as it progresses through these regimes.
\end{abstract}

\section{INTRODUCTION}

Graphene has risen to prominence as a versatile and scientifically intriguing material with tremendous potential. Making its fabrication a key research area extensively worked on by the scientific community at large. An intriguing and innovative rout to its synthesis is the spatially patterned reduction of the electrically insulating graphene oxide (GO) to the conductive reduced-graphene oxide (rGO).

This method opens up a top down fabrication approach for all-carbon based electronic devices with the ability to directly write conductive pathways into an electrically insulating material. The use of focused ion beam (FIB) irradiation to achieve this has been demonstrated ${ }^{1}$. Here we explore the sensitivity of this approach, analysing the key parameter of ion fluence.

Presented are the results of a systematic study where the ion fluence was varied from $0-0.204 \mathrm{nC} / \mu \mathrm{m}^{2}$, with analysis of Raman spectroscopy and atomic force microscopy (AFM) to determine the effect on the surface morphology of the sample. It is expected that increasing the fluence will result in the preferential reduction of the GO being overridden by amorphisation of the sample, leaving two regimes. One regime is where the major effect of ion irradiation is preferential removal of oxygen resulting in $\mathrm{rGO}$, and the other is where there is an increase in damage to the sample, leading to major disruptions of the carbon lattice and hence amorphisation. If the transition between these regimes is gradual it will allow for us to tune the effect of the irradiation, a key in using the FIB for the fabrication of micro to nanoscale patterns, to suit desired application.

\section{METHODOLOGY}

The GO was synthesized from graphite powder (SP-1 grade 325 mesh, Bay Carbon Inc.) using a modified Hummer method. It was then used to fabricate samples via spin coating on Si to make a continuous GO film that was $80 \mathrm{~nm}$ in thickness. The samples were then placed into the chamber of an FEI Helios Nanolab 600 FIB-SEM and pumped down to a vacuum level of below $1 \times 10^{-3} \mathrm{~Pa}$. Markers were milled into the surface using a $30 \mathrm{kV}$ beam, $9.3 \mathrm{nA}$ current with a fluence of $2.79 \mathrm{nC} / \mu \mathrm{m} 2$, and the area within the markers was exposed to a controlled fluence of Ga ions ranging from 0 to $0.204 \mathrm{nC} / \mu^{2}$. Raman spectra were obtained using a Renishaw Confocal micro-Raman Spectrometer equipped with a $\mathrm{HeNe}(632.8 \mathrm{~nm})$ laser calibrated to the silicon peak. Two point conductivity measurements were conducted using an Agilent B2900Series Precision Source/Measure Unit wired through an EmCal Genelyte Probe Station with 5 $\mu \mathrm{m}$ tipped tungsten probes. Measurements were taken by varying the applied voltage between $-4.5 \mathrm{~V}$ to $+4.5 \mathrm{~V}$. This range was deemed acceptable as studies have shown that $0-30 \mathrm{~V}$ range is required to stimulate electrically induced reduction of $\mathrm{GO}^{2}$. The probes were placed $50 \mu \mathrm{m}$ apart. The scan rate used in the measurements was $0.8 \mathrm{~V} / \mathrm{s}$ with a measurement taken every $0.008 \mathrm{~V}$. 


\section{RESULTS AND DISCUSSION}

Initial SEM images displaying the result of increasing fluence clearly show that at higher doses we have greater damage to the sample's surface as seen in figure 1 what is intriguing is the transition between the these two morphologies. From the Raman spectra of the FIB exposed regions seen in figure 2 it is evident that the sample undergoes different levels of reduction and amorphisation ${ }^{3}$ as we progressively increase the dosage of ions. At the maximum fluence studied 0.204 $\mathrm{nC} / \mu \mathrm{m}^{2}$ the sample is completely amorphised as is evident for the broad resonance peak. This is also reflected in the bulk conductivity measurements taken of the samples where the conductivity drops off at higher ion fluences. Initially the conductivity is low $\left(5 \times 10^{-4} \mathrm{~S} / \mathrm{m}\right)$ as graphene oxide is an insulating material due to the oxygen defects in its basal plane. Upon irradiation by the $\mathrm{Ga}$ ions (fluence $0.08 \mathrm{nC} / \mu^{2}$ ) the sample is reduced and this partially restores the $\mathrm{sp}^{2}$ honeycomb structure found in pristine graphene and hence increases its conductivity $\left(3 \times 10^{-1} \mathrm{~S} / \mathrm{m}\right)$ by 3 orders of magnitude. Finally at higher fluence values the ions do significant damage to the structure and the amorphisation hinders the electron mobility hence reducing the conductivity ${ }^{4}$ once again $\left(2.4 \times 10^{-6}\right)$.

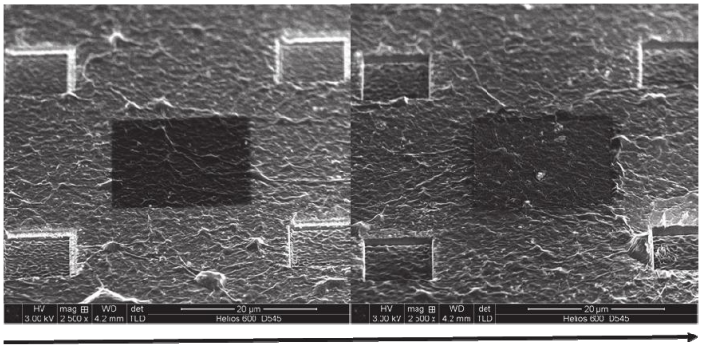

Figure 1. SEM images of the effect of increasing fluence on the GO sample there is an immediate change in contrast initially but it is clear that at higher fluences the surface undergoes significant damage.

Increasing Fluence

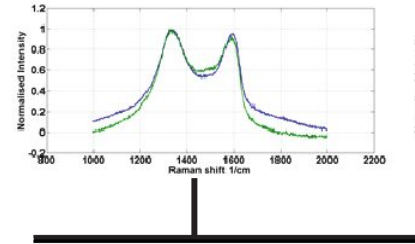

$4.00 \times 10^{-2} \mathrm{nC} / \mu \mathrm{m}^{2}$

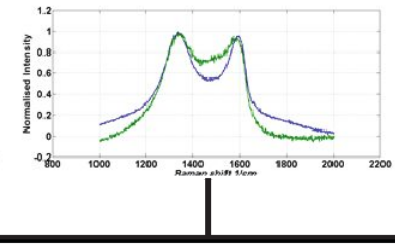

$5.60 \times 10^{-2} \mathrm{nC} / \mu \mathrm{m}^{2}$

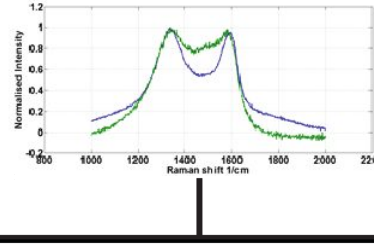

$8.00 \times 10^{-2} \mathrm{nC} / \mu \mathrm{m}^{2}$

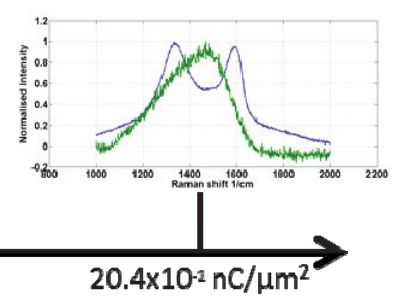

$20.4 \times 10^{-2} \mathrm{nC} / \mu \mathrm{m}^{2}$

Fluence

Figure 2. Optical images of the exposed regions with their corresponding Raman spectra, these results show us that the sample initially undergoes reduction and then at higher ion fluences amorphisation.

\section{CONCLUSIONS}

This work demonstrates that the FIB irradiation of graphene oxide is highly controllable, to the point where damage to the sample can be tuned between reduction and amorphisation. The maximum conductivity was obtained with a fluence of $0.08 \mathrm{nC} / \mu^{2}$ which lies in a region of reduction and amorphisation. This technique can be used as a tool to directly write all carbon conductive elements into an otherwise insulating film.

\section{REFERENCES}

1. Lobo, D. E.; Fu, J.; Gengenbach, T.; Majumder, M., Localized Deoxygenation and Direct Patterning of Graphene Oxide Films by Focused Ion Beams. Langmuir 2012, 28 (41), 14815-14821.

2. Y Yao, P.; Chen, P.; Jiang, L.; Zhao, H.; Zhu, H.; Zhou, D.; Hu, W.; Han, B.-H.; Liu, M., Electric Current Induced Reduction of Graphene Oxide and Its Application as Gap Electrodes in Organic Photoswitching Devices. Advanced Materials 2010, 22 (44), 5008-5012.

3. Ferrari, A. C.; Robertson, J., Interpretation of Raman spectra of disordered and amorphous carbon. Physical Review B 2000, 61 (20), 14095-14107.

4. $\quad$ Clark, G. J.; Marwick, A. D.; Koch, R. H.; Laibowitz, R. B., Effects of radiation damage in ion-implanted thin films of metal-oxide superconductors. Applied Physics Letters 1987, 51 (2), 139-141. 